\title{
ASPECTS UNDERLYING THE MODIFICATION OF BRIDAL COSTUME IN GORONTALO AT THE WEDDING RECEPTION
}

\author{
Hariana \\ Department of Fine Arts and Design, Universitas Negeri Gorontalo \\ The Study Program of Performing and Fine Arts Studies, \\ Universitas Gadjah Mada, Yogyakarta \\ G.R. Lono Lastoro Simatupang, Timbul Haryono, dan SP. Gustami \\ The Study Program of Performing and Fine Arts Studies, \\ Universitas Gadjah Mada, Yogyakarta
}

\begin{abstract}
ABSTRAK
Visualisasi busana pengantin perempuan masyarakat Gorontalo yang dikenakan pada resepsi pernikahan semakin beragam bentuk modifikasinya. Unsur-unsur desain busana pengantin yang termodifikasi terlihat pada unsur bentuk, tekstur, warna, bahan, dan ragam hias. Bentuk modifikasi busana pengantin perempuan masyarakat Gorontalo sekarang ini, menjadikan nilai fungsi busana berbeda dengan yang sudah dipolakan, dilihat dari nilai sosial, nilai simbolik, dan nilai ekonomi masyarakatnya. Metode pengumpulan data melalui studi literatur buku-buku dan hasil penelitian terkait busana pengantin, wawancara, dan pengamatan objek busana pengantin, dengan analisis data kualitatif. Pengamatan objek busana pengantin yang belum dimodifikasi dilakukan di Rumah Adat Dulahopa di Gorontalo, sedangkan objek busana pengantin yang sudah termodifikasi diamati berdasarkan busana yang banyak digunakan pengantin dalam rentang waktu dua tahun terakhir di Gorontalo. Tujuan penelitian ini adalah untuk menemukan aspek-aspek yang melatarbelakangi terciptanya modifikasi busana pengantin perempuan di Gorontalo. Hasil penelitian menunjukkan bahwa masyarakat Gorontalo cenderung memilih busana pengantin yang sudah termodifikasi dalam pelaksanaan pesta perkawinan. Ditemukan bahwa aspek-aspek yang melatarbelakangi terciptanya modifikasi busana pengantin adalah pengaruh status sosial dalam masyarakat, pengaruh masyarakat Gorontalo yang sudah tinggal di luar daerah asal, dan pengaruh teknologis.
\end{abstract}

Kata Kunci: Aspek Sosial; Aspek Teknologis; Busana Pengantin; Modifikasi.

\begin{abstract}
The visualization of the Gorontalonese bridal costume worn at the wedding reception is increasingly diverse in terms of the modification forms. The modification can be seen in the design elements including shape, texture, color, material, and accessory. Furthermore, the modification of the current costume makes the functional value of the bridal costume different from the already patterned one, which can be seen from its social, symbolic, and economic values of the Gorontalo community. The data in this study was collected through the review of books and previous studies related to the wedding clothing, the interviews, and the observation of bridal costumes and analyzed using the qualitative data analysis approach. The observation of unmodified bridal costume objects was done at the Dulahopa Traditional House in Gorontalo, while that of modified bridal costume objects was conducted on the widely used bridal costumes within the last two years in Gorontalo. The purpose of this study was to find out the aspects underlying the modification of bridal costume in Gorontalo. The results show that Gorontalo people tend to choose modified wedding dresses in the wedding party. Moreover,
\end{abstract}


this study suggests that the bridal costume modification is influenced by the family's social status in Gorontalonese community, migratory Gorontalonese people (staying outside the area of origin), and technological advancement.

Keywords: Bridal Costume; Modification; Social Aspect; Tecnological Aspect.

\section{INTRODUCTION}

The people of Gorontalo have a cultural diversity, including the traditional wedding costume. The use of the bride and groom costumes cannot be separated in the wedding party. Nevertheless, this study specifically discusses the object of the bridal costume since it has many elements of costume design that is highly possible to be modified.

Various forms of Gorontalonese bridal costume recently represent a form of that worn by the empress and princess in the heyday of the Kingdom of Gorontalo. The elements of the Gorontalonese traditional costume design as a royal fashion has a symbolic meaning associated with the life in the era of the kingdom. The transition of the clothing function from the royal fashion into a wedding dress creates its own meaning. Some of the fashion elements show accessory functions and some have symbolic meanings adapted to the previous ones.

The symbolic value of Gorontalonese bridal costume is symbolized through its clothing elements, including shape, texture, color, accessories, and formation. As claimed by Gustami (2008:4), accessories often contain certain symbolic values for their supportive communities like the philosophies of life and certain hopes. The accessories that have particular symbolic meanings will certainly not be (stay) as their original forms due to the development in various aspects.

The clothing field is dynamically developing and always changing at a certain time. The change of artwork is not only because a work is no longer considered important, but it can be caused by adjustments to certain aspects so as to be accepted by society (Hauser, 1985:521). The aesthetic character of Gorontalonese bridal costume which has many symbolic values lies in its silhouette, the number of attributes, color, accessories, and the way of its formation.

In this study, the phenomenon of the modification of Gorontalonese bridal costume was analyzed to investigate aspects underlying the modification of bridal costume in Gorontalo. The objects of the observed wedding costume are divided into two, i.e. unmodified costumes observed at the Doluhupa Traditional House in Gorontalo and modified costumes observed on those widely used within the last two years (2015-2017).

The values given by Edmun Burke's theory, three functions of art according to Feldman, personal functions of art, the social functions of art, and the phisycal fungctions of art (Feldman, 1967:4). Aspects to consider before designing using Victor Papanek (1985:7) theory "the function complex". In addition, the technological influence on the development of the bridal costume was examined based on the UNESCAP's (1989) theory which claims that a technology consists of four components, which interact with each other in a transformation process, including technoware, humanware, infoware, and orgaware. The objects of analysis in the UNESCAP's theory include technoware and inforware aspects. The technoware aspect includes tools and equipment (Lasalewo, 2010:66). Meanwhile, the technoware aspect referred to in this study includes tools, materials, and the process of the creation of bridal headwear.

This study was aimed at investigating aspects underlying the modification of the bride costume worn at a wedding reception in Gorontalo. The results of this study are expected to make the people of Gorontalo, especially the readers of this article, able to understand and interpret the aspects that give effect the birth of various forms of wedding dress modification. The data of this study was collected through literature review, interview, and the observation on the Gorontalo bridal costume objects, both unmodified and modified was done within the last two years (2015-2017). 
The literature review was focused on the research results related to the wedding dress. The interview was conducted on the people of Gorontalo who are related to the phenomenon of Gorontalonese bridal costume development, including providers of bridal equipment (fashion studios), bridal makeup artists, community leaders, and bridal costume users.

The observation was directly done on the displayed costumes, those worn by the brides, and wedding photos or videos. In the case of displayed costumes, the observation was conducted at the Dulohupa Traditional House in Gorontalo as an unmodified fashion. Costume objects in Dulohupa Traditional House, the elements of fashion designs still contained the symbolic values of Gorontalonese traditional dress. In addition, direct observations were also made at the wedding ceremonies in the region of Gorontalo so as to see the highly demanded fashion forms. Observations on photos of Gorontalonese marriage were also made to discover the development of Gorontalo bridal costume from 2015 to 2017. A qualitative data collection technique was needed to answer the problem statements.

The qualitative research analysis method included preparing and organizing data, reducing data, and displaying data (Creswell, 2015:251). Meanwhile, the data analysis employed sociological and technological approaches. Sachari (2005:149-150) stated that design objects can be observed through several approaches such as political, cultural, environmental, technological, aesthetic value, communication, social, and economic. This study applied two approaches from Sachari, e.i. tecnological and social. The descriptive analysis results found that there were several aspects underlying the modification of the bridal costume worn at the wedding reception in Gorontalo. These aspects include the social influence existing in the community, the influence of migratory people of Gorontalo, and the technological influence.

\section{DISCUSSION}

The modification of Gorontalonese bridal costume is influenced by social aspects and technological influence. Social aspect in question is the presence of social groups in the community and the existence of rantau community living outside the area of origin such as Jakarta. The development of clothing from time to time also influences the visualization of Gorontalonese current wedding dress. One aspect that promotes such a clothing development is the technological advances, such as those in the textile industry. Technological advances characterize that a community has undergone the development and alteration in the use of simple and traditional techniques towards the use of scientific knowledge (Weiner, 1977:60).

The development of the textile industry makes the visualization of the bridal costume more diverse from the material aspect and the way of its formation. The modified Gorontalonese wedding dress has given birth to different meanings and aesthetic values from before. Aryanto's (2008) study discussing the meaning of signs in modern bridal costume found a change in Javanese bridal costume as a result of the representation of cultural shifts and the blend of gamut values with the effects of modernization. Meanwhile, Meyrasyawati (2013) who studied the symbolization of culture and religion in Muslim Javanese wedding dress found that Muslim Javanese wedding dress has served as a means of creating the identity or popularity of the wearers.

Previous studies indicate that the form of wedding dress development has changed the previous meanings into different values. In other words, fashion elements which contain a symbolic meaning no longer correspond to what was symbolized before. In contrast to the previous studies, a study conducted by Wulandari et al., (2012) which investigated the role of Solonese bridal makeup artists found that the modified bridal makeup did not change the meaning beforehand. Based on the previous studies, the development of the wedding dress and bridal makeup does have different results. 
Wedding costume is much related to the elements of fashion design that form it, so it is possible to create new meanings. This is different from the modified bridal makeup, which is generally limited to the color aspect, the values contained can still be maintained. Any form of clothing development that becomes a fad will be a fashion followed by people either individually or communally. A fashion will apply at a certain place and time. A fashion is usually heavily influenced by clothing materials (Kawamura, 2005:4).

The phenomenon of the modification of Gorontalonese bridal costume is influenced by social aspects, namely social status in the society and the influence of migratory communities living outside the area of origin (in Jakarta). Humans as social beings will experience social changes that are influenced by various factors. External and internal factors include cultural (culture, sub-culture, and social class), social (reference groups, families, role, and status), personal (age, life cycle, occupation, economic situation, and lifestyle), and psychological (motivation, perception, learning, and trust) factors (Kotler, 1989).

From several factors put forward by Kotler, there are factors influencing the modification of Gorontalonese wedding costume, i.e. social factor, including the role and social class in society. The fashion modification will make the value of the fashion function different from before. The traditional wedding dress as an art product has certain symbolic meanings that have been already patterned. Art, as a product of a community, is created by taking into consideration a number of factors (Hauser,1985:92). Similarly, the wedding dress as a cultural object is designed by considering various factors. According to Citra, the owner of Busana Citra Modeste Studio, interviewed in Gorontalo on October 4, 2016, the main consideration in determining the materials used to make bridal costumes is the color and the radiance of the fabric. In term of the radiance, she prefers choosing lustrous fabrics, yet comfortable for use.

Consideratio ns in designing a wedding dress will depend on those involved in the de- sign process. The designers modify the Gorontalonese bridal costume by taking into account its artistic values. Art, as understood by people today, is linked to beauty, while beauty is understood as a certain quality or trait contained in a form or visual elements of art (Simatupang, 2013:6). The aesthetics focus more on the forms of art through the process of its creation. The aesthetic $v$ a lue itself is obtained from those who observe and enjoy an artwork.

Through an observation, one will have the ability to assess and appreciate a work of art. Assessing an artwork can be seen from its concept or idea of creation, creativity, or technique of creation. The results of this study indica te that the modification of the bridal costume used at the wedding reception in Gorontalo was influenced by family's social status in the community, the migratory people of Gorontalo, and technological factor.

\section{The Influence of Social Status}

The family's social status gives effect to the modified bridal wedding costume. The social layers of Gorontalo people are divided into two, namely pure and vague social layers. The pure social layer is manifested in power, religion, customary leader, and education, while the vague social layer is manifested by heredity, power, seniority, and education (Domili et al., 2000: 71-73).

Families are an environment closest to human life. For some people of Gorontalo, the family's influence still plays an important role in giving consideration related to how a marriage ceremony will look like. Through a marriage, a new family is formed and will enter within the scope of extended families. Therefore, a family has a role in preparing the traditional wedding party. Many things need to be prepared for the wedding party, including the preparation of wedding dress. In the past, all preparations for the marriage procession were arranged by the family, but it is now beginning to change. In choosing the wedding dress, the people of Gorontalo generally pay attention to their social status and their economic condition. 
A family with higher social status, as reflected by its powers or positions in government offices, tends to choose modified bridal costumes in the procession of marriage. A family that holds a position in the government tends to make their wedding luxurious and impressive. The impression of their luxurious wedding parties can be seen from the processes and the wedding costumes. This is what motivates the wedding dress studios or designers to modify the Gorontalo wedding dress. However, it was found that the community groups whose family members are government officials, although choosing modified costumes, still pay attention to the Gorontalo's cultural values which are visible on the clothing elements of structure and color.

The already patterned colors are called the tilabataila colors, which are red, yellow, green or purple. Yamin Husain, a Gorontalo's cultural elite, interviewed in Gorontalo on July 4, 2016, stated that certain colors excluding the established ones are allowed to use but no longer have symbolized values. The picture below shows the son of the Gorontalo Regent who chose to wear modified wedding costumes. Modifications are found in the costume accessories and on the back of the skirt coupled with a cloth that has a tassel. These tassels did not change the structure of the previous clothing.

The cultural values on the Gorontalonese bridal costume are found on the clothing form or silhouette, color, and attributes. The color is a clothing element that can be directly seen and known directly. The aesthetic features of Gorontalonese bridal colors are bright. Visually, bright colors in Gorontalonese bridal costume are to give the feel of joy and charm (Hariana, 2013). In term of color aspect, the selected colors should symbolize traditional colors, namely red, yellow, green, and purple. In its development, the bright dark is also used. Hue is a term used to refer to the name of a color, the value is the dark color, while intensity is related to the brightness or gloom of a color (Meilani, 2013:327). Creative colors are used more in the formation of hijab.

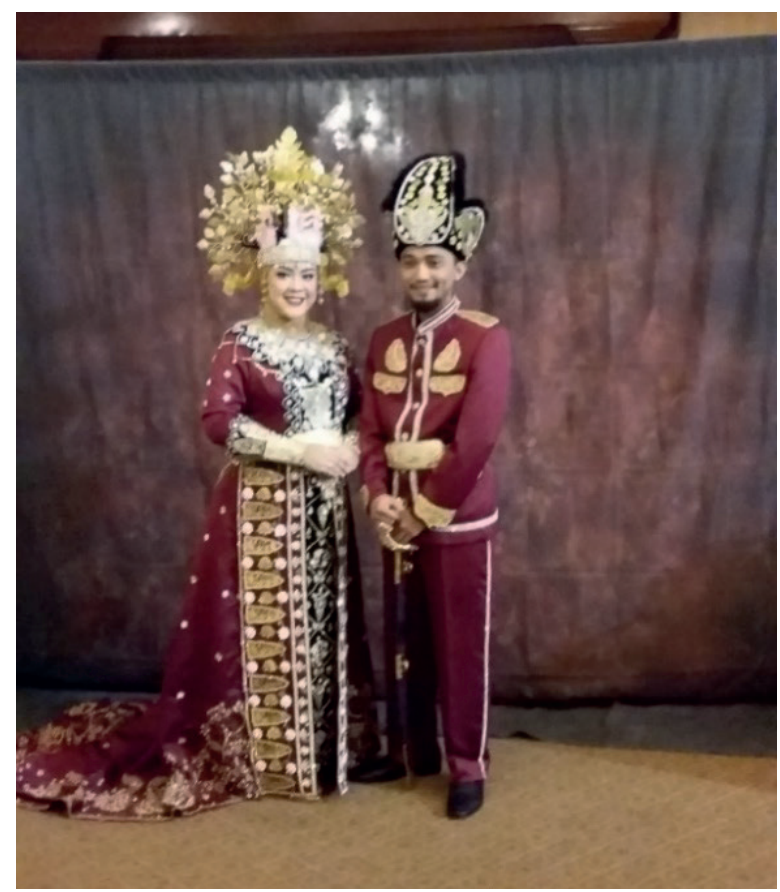

Figure 1. The form of the bridal costume modification at the wedding reception of the second son of the Gorontalo Regent

(Collection of Makuta Gorontalo Studio, edited on September 15, 2017)

Hijab is one aspect that is utilized to form new aesthetics in the Gorontalonese wedding dress. As revealed by Nasrullah (2013:243), when an image goes into Muslim fashion, then the process of its formation is no longer merely a cover of aurat (parts of the body which should not be exposed under Islamic religious law) but has another value. Setiawan also stated that there has been a change in the function of the underwear into a showy function that prioritizes the beauty of clothing. Clothing that is deliberately displayed for the showy purpose will have different functions from general casual clothing. The difference can be found in the media or material aspects used by Setiawan (2015:178).

Costumes worn by the Gorontalonese brides at their wedding party, in addition to functioning as a cultural object, serves as a showpiece. It is said the showpiece because the costume is selected by taking into account a variety of considerations in order to appear attractive in front of the invited guests. The 
development in the form aspect includes the outline of costume, i.e. the clothes, skirts, breast cover, and hand cover (still using the actual forms).

The form modification is seen in the silhouette, which should be loosely sized, turning into a size following the shape of the bridal body. Rasni, the owner of Tri Nur Clothing Studio, interviewed in Gorontalo on October 4, 2016, stated that Gorontalo people currently prefer choosing a wedding costume whose the size of the upper part and the lower part (skirt) fits the body (not loose). As admitted by Erna, a bridal costume's consumer, interviewed in Gorontalo on October 4, a wedding dress will be comfortable to use if the size fits the body shape. This is evidenced by the observations on the costumes worn by the brides that generally follow the shape of the bride's body.

The accessory aspect is also maintained by using attributes made of metal (brass or silver). Haryono (2001:21) suggests three forms of material culture, i.e. subsystem, technology, and sociology. Metal is one form of material used to create an attribute of Gorontalo wedding dress followed by cultural symbols through its accessory variety.

An accessory often contains symbolic values for the supportive community and contains life views and philosophies as well as certain hopes (Gustami, 2008:4). The additional accessories that can more beautify the look of the wedding costume include sparkling beads and gemstones. An accessory variety, in addition to serving to give symbolic meanings, also aims to increase the value of its beauty. As claimed by Kuntjoro-Jakti (2010:248), accessories as a cultural element are aimed to achieve an aesthetic value in a particular social context. For instance, accessories in Minangkabau traditional wedding dress imply messages about the guidance to achieve a happy life (Maresa, 2009:269). Similarly, the accessories of the Gorontalonese wedding dress have a meaning that aims to guide the bride and groom to create a prosperous and happy family.
The development of fashion has led the people of Gorontalo to no longer focus on symbols as a basis for selecting the wedding dress to be used. Currently, the selection of wedding dress is considered more on the social status in a community. Ordinary/general people tend to choose a wedding dress based on their economic ability. The economic factor becomes a consideration so as to adjust to the bride family's ability. The family must have a calculation of the costs of the wedding. Therefore, an income affects a person in choosing a wedding dress.

\section{The Influence of Migratory Community}

The migratory people living outside their area of origin (Gorontalo) who are directly involved as the providers of wedding fashion equipment will greatly influence the birth of various modifications to Gorontalonese wedding costume. Fashion studios located outside the area of origin such as Jakarta highly influence the birth of modified forms of wedding dress. Jakarta as a metropolitan city enables many opportunities for making wedding dress creative designs. The availability of tools and materials in big cities contribute to generating more attractive fashion ideas.

Based on the preliminary study, there are factors that influence the birth of modifications to Gorontalonese bridal costume, i.e. technological and sociological factors (Hariana et al., 2016). Technological factors include tools, materials, the process of creation, and the influence of social media. While social factors are related to the ideas of the fashion designers. Clothing designs will always pay attention to fashion trends in certain periods.

Clothing which has an artistic value cannot be separated from the design visualization, including the clothing elements. The embodiment of clothing through the design process can mean piece, model, shape, or good, nice or beautiful shape (Tahid \& Nurcahyanie, 2007:37). All human activities are designs because an activity starts from plan- 
ning to achieve certain goals. A design is the main matrix in human life or design is the conscious effort to impose meaningful order. A design should be planned in order to make it better or more meaningful than before. Therefore, a design must have a purpose and a function (Papanek, 1985:3-4).

Gorontalo people, in modifying the bridal costumes, are very dependent on the availability of tools and materials in the region of Gorontalo. The modification also takes into consideration who the wearer is. If the target consumers can afford a high price, the designers will be willing to seek a variety of good quality accessories, even until outside of the region of Gorontalo. But on the other hand, consumers who can only afford a lower price can use accessories that are already available in Gorontalo so as not to incur additional costs such as the delivery fee.

This indicates that the creative ideas of the Gorontalonese bridal costume are influenced by the technological advances. As suggested by Wagiran (2007:42), the field of information and technology has an effect on the human life, i.e. generating new thinking.

\section{The Influence of Tools, Materials, and Process}

The role of technological aspect in the modification of Gorontalonese wedding costume is seen in the availability of adequate tools and materials, as well as the growing influence of social media. The increasingly varied tools and materials highly contribute to growing the wedding fashion. The aesthetic features of the Gorontalo bridal attribute are made of brass. Formerly, the attributes of Gorontalonese bridal costumes were made manually using the tatah technique. In its development, the tatah technique is replaced with the ketok technique. Although the ketok technique is done also manually, the process is easier and faster than using the tatah technique. These two techniques create different aesthetic values. The tatah technique produces attribute with more raised shapes than the ketok technique. The difference of the end results of the costume attributes made using the tatah and ketok techniques can be seen in the following Figure.

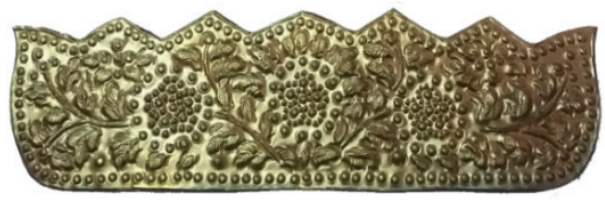

Figure 2. The attributes of the head part made using the tatah technique

(Author Documentation, Yogyakarta June 29, 2016)

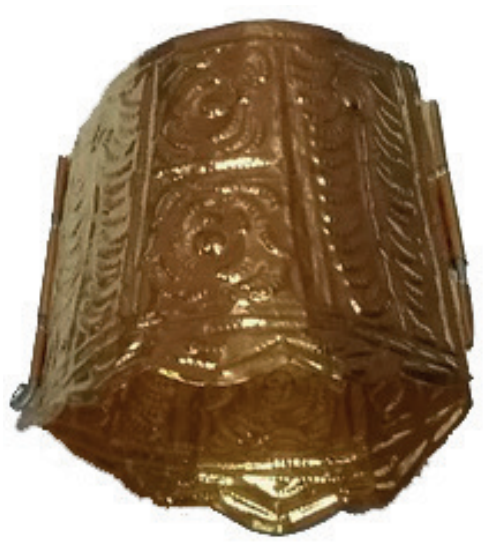

Figure 3. Attribute bridal costume/bracelet using ketok technique

(Author Documentation, Gorontalo July 4, 2016)

The Gorontalo bridal costume attributes made using the tatah technique look more aroused than using the ketok technique. The fashion studios prefer making clothing attributes using the ketok technique. This technique is chosen because the process is faster and the cost is cheaper. As time goes by, the material to make the attributes is not only brass but also other materials, including self-formed textile materials and alreadyformed textile materials which resemble the attributes of Gorontalo bridal costume. The picture below is a modified form of the decoration of the skirt that should use the material of brass made modification of the textile material. 


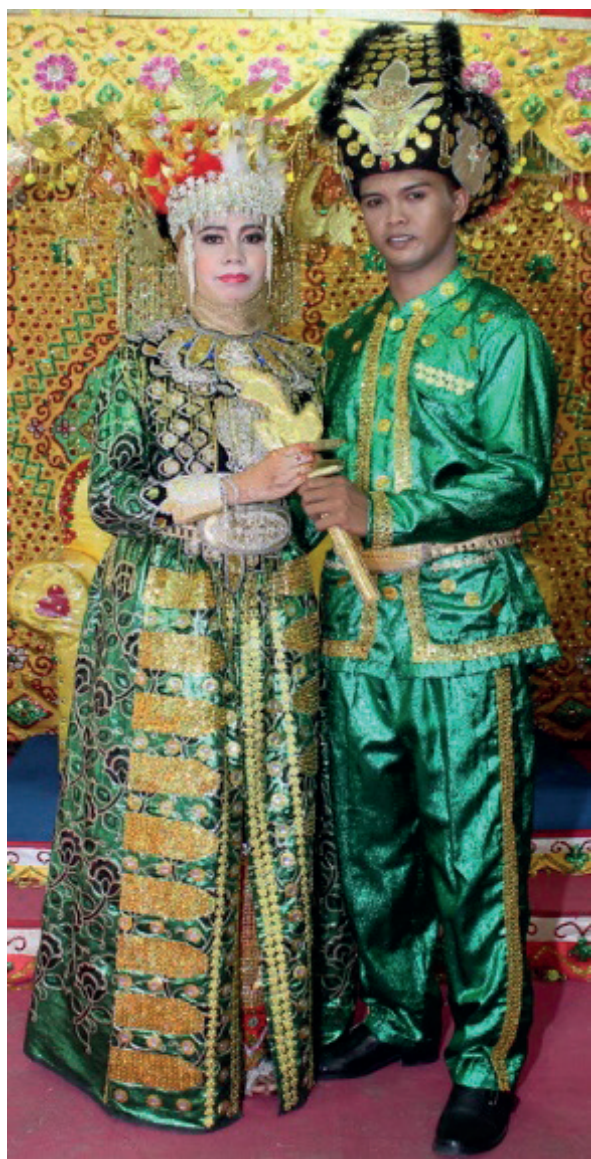

Figure 4. Modification on decoration skirt (Vivin Documentation, Gorontalo August 10, 2015)

The modification is also found on the bridal costume bracelets which are modified by utilizing golden yellow fabrics added with accessory gems as illustrated in the following Figure.
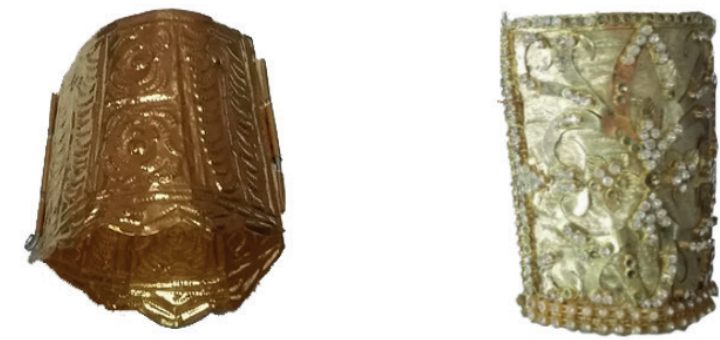

Figure 5. A. Bridal bracelets made of brass; B. Modified bracelets made of cloth and decorated with gems

(Author Documentation, Jakarta September 15, 2017)
The fashion studios that still use brass for their bridal attributes prefer ordering the attributes outside the area of origin, especially from Yogyakarta. In this war, the studios can get a cheaper price. This is because, in Java, the raw materials for the attributes are easy to obtain. In addition, the attributes of the wedding dress can be made either manually or using a machine. The machine-driven technique makes the products much smoother, the process faster, and the cost cheaper.

The textile materials in the form of cloths used to make the wedding clothes and skirts are also more varied. Generally, the materials are chosen to make the bridal costumes by considering the texture of the materials. The smooth, sleek, and lustrous $m$ aterials are chosen. These features are found in satin and silk. The bridal dress producers prefer satin to silk since the selling price of satin is cheaper than that of silk. Silk fabrics are usually chosen to make a combination of hijab. Wearing a hijab is considered a fantasy of enjoyment of other forms of hijab clothing as part of the accessories. The phenomenon of wearing the hijab is part of the fashion trend (Suhendra, 2013:18).

\section{The Influence of Social Media}

Another role of technological aspects in the modification of Gorontalonese wedding costume is the influence of social media. The internet as a social media is considered a fast way of accessing information about the latest fashion trends. The designers of traditional wedding dresses need to have an artistic insight, socio-cultural understanding, and understanding of aesthetic value. Such understanding is necessary so the created clothing contains an artistic value. Instagram, one of the social media apps, has an important role in displaying modified Gorontalonese bridal costumes. The wedding dress service providers admit that it is very easy to promote their products through Instagram. A fashion studio or a bridal makeup artist uploading photos of wedding parties/ceremonies using his/her service is one form of communication media. 
Through uploading such photos, fashion studios and wedding makeup artists will spread a lot of information about the services/ products they offer/sell. Frequently, if many people like the photos, the potential users/ customers will be interested to use the products/services or recommend them to friends or family. The people of Gorontalo, in choosing their favorite wedding costumes to be worn at the wedding ceremony, are much inspired by social media such as Instagram and Facebook. These social media apps are utilized by the owners of wedding dress rental services in Gorontalo to promote their products. It also allows the rental service customers to access the desired fashion by visiting their social media account homes. A wedding dress is one of the art products shown to the wider community in the wedding procession. According to Morris (Morris, 2002:319-321), clothing has three functions, i.e. comfort-protection, cultural display, and modesty. An embodiment of clothing will be in accordance with its function as it is made by taking into account the visual elements. Its social function will indirectly affect the various groups of people present at a wedding party by way of thinking or feeling so it can affect the way they act (Feldman 1967:38).

\section{CONCLUSIONS}

There are two factors that contribute to the creation of modified bridal costume in Gorontalo, i.e. social and technological factors. The social factor includes the desire of the bride's family or the bride herself to appear luxurious and impressive on the day of her marriage. Other factors are higher family social status such as families holding power or position in government offices, as well as the increasingly widespread role of social media in spreading fashion fashions. The technological aspect includes the interaction between tools, materials, and processes in making a more varied bride costume. Another technological aspect is the influence of social media.

Gorontalo people, in general, have chosen a modified wedding dress to wear at the wedding. Groups of people who have powers or positions in government offices tend to choose modified wedding costumes but still pay attention to the Gorontalo's cultural aspects. Aspects that are still maintained include the structure, color, and metal attributes although these elements are considered expensive. Meanwhile, groups of general people tend to pay attention to the price in choosing a modified wedding dress. The local designers in Gorontalo have already had the creative ideas of modifying the Gorontalonese bridal costume. These ideas are emerged due to the availability of new tools, materials, and new techniques for creating and utilizing the available technology. The following Figure shows a modified bridal costume that uses a variety of accessories from textile materials in lieu of costume attributes made of brass.

A modified bridal costume can have functional values if it is made using certain considerations, including to whom the wedding dress is made (social class), the trend in the bridal costume, and the technology related to the availability of tools, materials, and the creating processes.

Through this study, it is hoped that the phenomenon of Gorontalonese bridal costume development receives the attention from related stakeholders in the region of Gorontalo. They are expected to observe the extent to which the development of Gorontalonese wedding costume is influenced by various aspects. In this way, the aspects that influence such a development can be further analysis materials to satisfy the needs of the people of Gorontalo in general. They are also encouraged to take into consideration the way the wedding costume is modified by not eliminating its aesthetic characteristics as a manifestation of Goronatalonese culture.

\section{RESPONDENS}

1. Bapak Yamin Husain

A Gorontalo's cultural elite, interviewed in Gorontalo on July 4, 2016.

2. Ibu Citra

As the owner of a clothing studio 'Citra Modeste, interviewed in Gorontalo on October 4, 2016. 
3. Ibu Rasni

As the owner of a clothing studio "Tri Nur" interviewed in Gorontalo on October 4, 2016.

4. Ibu Vivin

As a consumer of bridal costume, married in Gorontalo August 10, 2015.

5. Ibu Erna

As a consumer of bridal costume, married in Gorontalo November 14, 2015.

\section{BIBLIOGRAPY}

Aryanto, H. (2008). Makna Tanda Pada Fesyen Pengantin Jawa Bergaya Modern. Nirmana, 10(1), 26-31.

Creswell, J. W. (2015). Penelitian Kualitatif \& Desain Riset. Yogyakarta: Pustaka Pelajar.

Domili, B., Djakaria, S., Katuuk, E., Tangkilisan, M., \& Tambajong. (n.d.). Budaya Masyarakat Suku Bangsa Gorontalo Di Kabupaten Gorontalo. Gorontalo: Departemen Pendidikan Nasional Proyek Pengkajian Dan Pembinaan Nilai-Nilai Budaya Sulawesi Utara.

Feldman, E. B. (1967). Art as Image and Idea. New Jersey: Prentice-Hall, Inc.

Gustami, SP (2008). Nukilan Seni Ornamen Indonesia. Yogyakarta: Jurusan Kriya FSR ISI.

Hariana. (2013). Kajian Semiotika Fashion Dengan Objek Desain Busana Tradisional. In Seminar Nasional 2013 "Kesiapan SMK dalam Implementasi Kurikulum 2013" (pp. 448-456). Yogyakarta: Jurusan PTBB FT UNY.

Hariana, Simatupang, L. L., Haryono, T., \& Gustami, SP. (2016). Modifikasi Busana Bili'u dan Paluwala Sebagai Pakaian Perkawinan Masyarakat Gorontalo: Aspek Sosiologi dan Teknologis. In Seminar Nasional Dalam Rangka Konvensi Nasional VIII APTEKINDO dan Temu Karya XIX FT/FPTK Se-Indonesia Medan,
3 - 6 Agustus 2016. Medan: Fakultas Teknik Universitas Negeri Medan.

Haryono, T. (2001). Logam dan Peradaban Manusia. Yogyakarta: Philosophy Press.

Hauser, A. (1985). The Sociology of Art: Trans. Kenneth J. Nortcott. Chicago and London: University of of Chicago Press.

Kawamura, Y. (2005). Fashion-ology: An Introduction to Fashion Studies. Oxford, New York: Berg Publisher.

Kotler, P. (1989). Manajemen Pemasaran. Jakarta: Erlangga.

Kuntjoro-Jakti, R.A . D. R. (2010). Ragam Hias Nusantara. Humaniora, 1(2), 246-252.

Lasalewo, T. (2010). Strategi Industri. Bandung: Wahana Media Pustaka.

Maresa, A. (2009). Estetika Simbolis Dalam Busana Pengantin Adat Minangkabau DI Padang. Filsafat, 19(3), 255-272.

Meilani. (2013). Teori Warna: Penerapan Lingkaran Warna dalam Berbusana. Humaniora, 4(9), 326-338.

Meyrasyawati, D. (2013). Fesyen dan Identitas: Simbolisasi Budaya dan Agama Dalam Busana Pengantin Jawa Muslim Di Surabaya. Jurnal Makara Seri Sosial Humaniora, 17(2), 99-108.

Morris, D. (2002). People Watching: The Desmond Morris Guide to Body Language. London: Vintage.

Nasrullah, R. (2013). Semiotika Naratif Greimasian Dalam Iklan Busana muslim. Journal Kawistara, 3(3), 227334.

Papanek, V. (1985). Design For The Real World: Human Ecology and Social Change. London: Thames.

Sachari, A. (2005). Pengantar Metodologi Penelitian Budaya Rupa - Desain, Arsitektur, Seni Rupa dan Kriya. Jakarta: Erlangga. 
Setiawan, D. (2015). Konsep Pakaian Jogya Fashion Week Carnival Dalam Struktur Sosial DI Yogyakarta. Journal Kawistara, 5(2).

Simatupang, L.L (2013). Pergelaran: Sebuah Mozaik Penelitian Seni Budaya. Yogyakarta: Jalasutra.

Suhendra, A. (2013). Kontestasi Identitas Melalui Pergeseran Interpretasi Hijab Dan Jilbab Dalam Al Qur' an. Palastren, 6(1), 1-22.

Tahid, S., \& Nurcahyanie, Y. (2007). Konsep Teknologi dalam Pengembangan Produk Industri. Jakarta: Prenada Media Group.
UNESCAP. (1989). Technology Atlas Project. A Framework For Technology Based Development: Technology Content Assessment \& Technology Climate Assessment (Vol. 2 \& 3).

Wagiran. (2007). Inovasi Pembelajaran Dalam Penyiapan Tenaga Kerja Masa Depan. Jurnal Pendidikan Teknologi Dan Kejuruan, 16(1), 41-55.

Weiner, M. (1977). Modernisasi Dinamika Pertumbuhan. Yogyakarta: Gadjah Mada University Press.

Wulandari, Y. N., Marwiyah, \& Setyowati, E. (2012). Peranan Juru Rias pengantin Terhadap Pelestarian Tata Rias dan Busana Pengantin Adat Solo. Journal of Beauty and Beauty Health Education, 1(1), 10-14. 